\title{
EFFECTIVENESS OF THE PROCESS OF CLEANING NATURAL ALFALFA (Medicago sativa L.) AND RED CLOVER (Trifolium pratense L.) SEEDS EFEKTIVNOST PROCESA ČIŠĆENJA NATURALNOG SEMENA LUCERKE (Medicago sativa L.) I CRVENE DETELINE (Trifolium pratense L.)
}

\author{
Dragoslav ĐOKIĆ*, Rade STANISAVLJEVIC ${ }^{* * *}$, Jasmina MILENKOVIĆ, \\ Ranko KOPRIVICA ${ }^{* * *}$, Jasmina KNEŽEVIĆ ${ }^{* * * *}$, Aleksandar VUKOVIC ${ }^{* * * * *}$, Dragan TERZIĆ ${ }^{* * * * *}$, \\ *Institute for forage crops Kruševac, 37251 Globoder-Kruševac, Serbia \\ *** Institute for plant protection and the environment, Teodora Drajzera 9, 11000 Belgrade, Serbia \\ ${ }^{* * *}$ University of Kragujevac, Faculty of agronomy, Cara Dušana 9, 32000 Čačak, Serbia \\ ${ }^{* * *}$ University of Priština, Faculty of agriculture, Kopaonička bb, 38219 Lešak, Serbia \\ University of Niš, Faculty of agriculture, Kosančićeva 4, 37000 Kruševac, Serbia \\ email: dragoslav.djokic@ikbks.com
}

\begin{abstract}
This paper presents the results of the cleaning tests of three different natural alfalfa seed lots and three different red clover seed lots performed using seed processing machines. The alfalfa (Medicago sativa L.) and the red clover (Trifolium pratense L.) are two of the most important perennial forage legumes in the Republic of Serbia. Alfalfa and red clover seeds for sowing should be clean, i.e. free from weeds and foreign matter, and of high germination and genetic values. Such requirements can only be achieved by cleaning, i.e. removing all undesirable impurities and poor-quality seeds. The following parameters important for the seed cleaning process and equipment were observed: seed purity, contents of weed and other crop seeds, inert substance content, amounts of processed seeds $(\mathrm{kg})$, seed loss and processing output. The results obtained facilitate (depending on the amount and type of weeds and other impurities found in the alfalfa and red clover seed lots considered) the proper adjustment of the seed processing equipment to obtain the largest possible quantity of quality seeds that are in compliance with the laws and regulations of Serbia.
\end{abstract}

Key words: alfalfa, red clover, seeds, cleaning, weeds

\section{REZIME}

U radu su prikazani rezultati ispitivanja pri čišćenju tri različite partije naturalnog semena lucerke i tri različite partije crvene deteline na mašinama za doradu, odnosno određeni su svi relevantni parametri na mašinama za doradu. Lucerka (Medicago sativa L.) i crvena detelina (Trifolium pratense L.) su dve najvažnije višegodišnje krmne biljke u Republici Srbiji. Njihov značaj se ogleda kako po površinama na kojima se gaje, tako i zbog proizvodnje izuzetno kvalitetne stočne hrane. Da bi se dobile dovoljne količine kabastog hraniva od ove dve krmne biljke potrebno je obaviti kvalitetnu setvu koja je jedna od najvažnijih agrotehničkih mera od čije uspešnosti zavisi prinos i kvalitet biljaka. Seme za setvu mora da bude čisto, bez korova i stranih primesa, visoke klijavosti i genetske vrednosti. Ove zahteve moguće je ostvariti samo čišćenjem, odnosno odstranjivanjem svih nepoželjnih primesa i semena lošijeg kvaliteta. Čišćenje semena se obavlja na različitim mašinama koje rade na principu razlika u fizičkim osobinama semena. Iz naturalnog semena s primesama čišćenjem se uklanjaju razne nečistoće i izdvaja se čisto zrno osnovne kulture. Relevantni parametri značajni za mašine za čišćenje semena lucerke i crvene deteline koji su određeni pri procesu dorade bili su: čistoća semena, sadržaj semena korova i semena drugih kultura, sadržaj inertnih materija, količina dorađenog semena (kg), gubici semena $i$ randman dorade. Dobijeni rezultati omogućavaju da se u zavisnosti od količine $i$ vrste korova $i$ ostalih primesa koje se nalaze u različitim partijama naturalng semena lucerke i crvene deteline obavi pravilno podešavanje mašina za doradu radi dobijanja što veće količine kvalitetnog semena koje odgovara zakonskim propisima.

Ključne reči: lucerka, crvena detelina, seme, čišćenje, korovi.

\section{INTRODUCTION}

The alfalfa (Medicago sativa L.) and the red clover (Trifolium pratense L.) are two of the most important perennial forage plants for domestic animal nutrition in the Republic of Serbia. They are used directly as green fodder for grazing, both in pure stands and in a mixture with grasses, or in a preserved form such as hay, silage or flour (Vučković, 1999). Both plants are characterized by high biomass yields, forage quality and rapid regeneration after mowing (Ocokoljić, 1974; Lugić et al., 2000; Marković et al., 2007; Vasiljević et al., 2011; Knežević and Stanisavljević, 2018). Sufficient amounts of fodder nutrients can be obtained from these two forage crops by quality sowing. Sowing is one of the most important cultural practices that greatly affect the yield and quality of plants. Seeds for sowing must be of high germination and genetic values and free from weeds and foreign matter. Quality seeds can only be obtained by cleaning or removing undesirable impurities and inferior-quality seeds. Seed cleaning is performed using different machines that work on the principle of difference in the physical properties of seeds. The following physical properties of seeds are considered most important for processing: moisture, shape, dimensions, sphericity, mass of 1000 seeds, volume and porosity, volume-hectolitre mass, density, static and dynamic angles of internal friction (angle of free fall), and the static coefficient of surface friction (Babić and Babić, 2012; Baskakov et al., 2018; Black et al., 2006; Copeland and McDonald, 2004; Djokić and Stanisavljević, 2012; Djokić et al., 2012; Koprivica, 2018). A good knowledge of all the physical properties of crop seeds is important for designing seed sowing, drying and processing equipment, harvesting and transporting crops, and storage facility construction. A number of different technological operations are performed in a specific order (Djokić et al., 2018). Immediately after harvest, natural seed is a very complex mechanical mixture containing large and small weeds, impurities of organic and inorganic origin, and whole, crusty and broken seeds. Seed processing, as part of seed production, is a very complex process with significant energy requirements (Orobinsky et al., 2017). The amount of quality seeds obtained depends on the content of impurities and the quantity and type of 
weeds in the seed processed. Natural seed purification is a process in which various impurities and poor-quality seeds, as well as weed and other crop seeds, are removed from the quality seeds of the basic crop (Djokić at al., 2016; Djokić at al., 2017).

There are different stages of seed processing, one of which is cleaning seeds using machines for additional weed cleaning. Alongside pneumatic tables, friction and electromagnetic separators are also used for seed cleaning. Electromagnetic cleaning machines are greatly favoured for their high-quality cleaning performance. Such high purity cannot be achieved by pneumatic, trier or screen cleaning (Kozlov, 2013). According to some authors (Djukić et al., 2004; Karagić et al., 2007), weed species in alfalfa and red clover crops impede the harvesting process, contaminate alfalfa and red clover seeds and hinder their processing. The presence of dodder seeds (of the quarantine weed Cuscuta spp.) is particularly harmful to crops. The dodder is one of the most dangerous and economically damaging weeds, especially if it is not timely controlled. Seed products must meet the production and market standards of quality and comply with the Serbian regulations for packaging and labelling seeds. The Law on Seeds and Planting Material (Official Gazette of the Republic of Serbia, No. 45, 2005) defines all the conditions relative to the methods of agricultural seed production, processing, use, marketing, import and testing. The quality of alfalfa and red clover seeds must comply with the Official Gazette of SFRJ No. 47/87. Processed alfalfa and red clover seeds must have a minimum purity of $95 \%, 2 \%$ of other crop seeds, no more than $0.5 \%$ of weeds, with the exception of the quarantine weeds dodder (Cuscuta spp) and curly dock (Rumex crispus), a minimum germination of $70 \%$ and a seed moisture content of up to $13 \%$. The objective of the tests performed was to determine and examine all the parameters relevant to the processing of different natural alfalfa and red clover seeds and the equipment used therein, thus indicating their overall effectiveness.

\section{MATERIAL AND METHOD}

The experimental tests were performed at the seed processing centre of the Institute for Forage Crops in Kruševac. They involved a total of six lots of natural alfalfa and red clover seeds, i.e. three lots of each, and were conducted in three replications. The Danish Kongskilde and Damas equipment was used for seed processing, whereas the German Emceka Gompper (type 4) electromagnetic separator was used for final weed cleaning. The equipment used consists of an intake pit with a belt conveyor, bucket elevators, conveyor belts and a machine for fine cleaning (the Alfa- 4 type). The Alfa- 4 machine for fine seed cleaning consists of two shaker shoes with six sieves arranged in two levels. For the processing of natural alfalfa seeds, the upper sieves of the upper shaker shoe had round openings of the following diameters: $2.75 \mathrm{~mm}$; $2.5 \mathrm{~mm} ; 2.25$ $\mathrm{mm}$. However, the lower sieve round openings of the upper shaker shoe were $2.0 \mathrm{~mm}, 2.0 \mathrm{~mm}$ and $1.9 \mathrm{~mm}$. The upper sieves of the lower shaker shoe had longitudinal openings of the following widths: $1.3 \mathrm{~mm}, 1.2 \mathrm{~mm}$ and $1.1 \mathrm{~mm}$. However, the longitudinal opening widths of the lower sieves of the lower shaker shoe were $0.6 \mathrm{~mm}, 0.5 \mathrm{~mm}$ and $0.5 \mathrm{~mm}$.

In the processing of red clover seeds, the sieves of the upper shaker shoe had round openings of the following diameters: 2.75 $\mathrm{mm}, 2.5 \mathrm{~mm}, 2.25 \mathrm{~mm}, 2.2 \mathrm{~mm}, 1.9 \mathrm{~mm}$ and $1.9 \mathrm{~mm}$. However, the sieves of the lower shaker shoe had longitudinal openings of the following widths: $1.4 \mathrm{~mm}, 1.3 \mathrm{~mm}, 1.2 \mathrm{~mm}, 0.6 \mathrm{~mm}, 0.5 \mathrm{~mm}$ and $0.5 \mathrm{~mm}$. The final cleaning of weeds and other impurities was performed using an electromagnetic separator machine with rollers. The US Nutra fine RS steel powder was used to clean the seeds on the electromagnetic separator machine. The laboratory seed purity analysis was performed using a magnifier with illumination. A precise electronic scale was used to measure the mass of the samples, which were $5 \mathrm{~g}$ (the working sample) and $50 \mathrm{~g}$ (the submitted sample). Measurements of the natural and processed seed masses were carried out using an electronic weighing range of up to $300 \mathrm{~kg}$. The following seed parameters were analyzed: seed purity (\%), seeds of other species (\%), inert matter (\%) and weed seeds (\%). At the end of seed processing, the amount of processed seeds $(\mathrm{kg})$ was measured. The seed processing output (\%) and losses were calculated for the processing equipment used (\%).

The Tukey's multiple range tests $(p \leq 0.05)$ were used to determine the effect of the seed treatments performed. The results obtained were statistically processed using the Minitab Inc. Program, 16.1.0, State College, Pennsylvania, USA.

\section{RESULTS AND DISCUSSION}

The average purity of the natural alfalfa seeds from all three lots considered is shown in Table 1 . The natural alfalfa seed purity ranged from $70 \%$ in the lot I seeds to $86 \%$ in the seeds from the lots II and III. From a statistical perspective, the seeds from the lots II and III had a significantly higher purity ( $\mathrm{p} \leq$ 0.05 ) than the lot I seeds. Upon analysis, no other species were found in all three experimental lots of natural alfalfa seeds. The content of inert matter, in the form of soil and seed, was the highest in the lot I natural alfalfa seeds, amounting to $30 \%$. However, the inert matter contents of the natural alfalfa seeds from the lots II and III were $14 \%$ and $9.8 \%$, respectively. The presence of plantains (Plantago sp), a grass mix (Poa sp) and five seeds of the dodder (Cuscuta spp) was determined in the alfalfa lot I working sample. The lot II working sample contained barnyard grass (Setaria spp), chamomile (Matricaria chamomilla) and mixed grass (Poa sp) seeds. In addition to 4.2 $\%$ of weeds, sorghum (Sorghum halepense) and barnyard grass (Setaria spp) seeds were also found in the lot III working sample.

Table 1. The average purity of natural alfalfa seeds

\begin{tabular}{|c|c|c|c|}
\hline Lot & I & II & III \\
\hline Seed structure & $\%$ & $\%$ & $\%$ \\
\hline Pure seed & $70.0 \mathrm{~b}$ & $86.0 \mathrm{a}$ & $86.0 \mathrm{a}$ \\
\hline Other species & 0 & 0 & 0 \\
\hline Inert matter & $30.0 \mathrm{a}$ & $14.0 \mathrm{~b}$ & $9.8 \mathrm{c}$ \\
\hline Weeds & $\begin{array}{c}\text { "TR“ Plantago } \\
\text { sp, Poa sp, } \\
\text { 5 seeds of } \\
\text { Cuscuta } \mathrm{spp}\end{array}$ & $\begin{array}{c}\text { "TR“ Setaria } \\
\text { spp, Matricaria } \\
\text { chamomilla, } \\
\text { Poa sp }\end{array}$ & $\begin{array}{c}4.2 \text { Sorghum } \\
\text { halepense, } \\
\text { Setaria } \mathrm{spp}\end{array}$ \\
\hline Total & 100 & 100 & 100 \\
\hline
\end{tabular}

The average purity of the natural red clover seeds from all three lots considered is shown in Table 2 . The natural red clover seed purity ranged from $74 \%$ in the lot I seeds to $80 \%$ in the seeds from the lots II and III. The red clover seeds from the lots II and III had a significantly higher $(\mathrm{p} \leq 0.05)$ average purity than the lot I seeds. Upon laboratory analysis, seeds of other plant species were not found in the lot I and III seed samples. However, the lot II red clover sample contained $1 \%$ of alfalfa seeds. The inert matter in the form of soil was the highest in the lot I seeds, amounting to $26 \%$. The inert matter in the form of flowers and broken seeds accounted for $19.0 \%$ of the lot II red clovers seeds. The inert matter in the form of harvest residues accounted for $16.5 \%$ of the lot III red clover seeds. The content of weeds was the highest in the lot III seeds (3.5\%), with a high content of the quarantine weed dodder. In the $5 \mathrm{~g}$ sample of the lot III seeds, a total of 20 dodder seeds (Cuscuta spp) were found, as well as some plantain (Plantago sp) and chamomile (Matricaria chamomilla) seeds. A total of 6 pigweed (Amaranthus retrofleksus) seeds were found in the $5 \mathrm{~g}$ sample of the seeds from the lot I, whereas a total of two dodder seeds (Cuscuta spp) were found in the $5 \mathrm{~g}$ sample of the lot II seeds. 
Table 2. The average purity of natural red clover seeds

\begin{tabular}{|c|c|c|c|}
\hline Lot & I & II & III \\
\hline Seed structure & $\%$ & $\%$ & $\%$ \\
\hline Pure seed & $74.0 \mathrm{~b}$ & $80.0 \mathrm{a}$ & $80.0 \mathrm{a}$ \\
\hline Other species & 0 & 1.0 & 0 \\
\hline Inert matter & $26.0 \mathrm{a}$ & $19.0 \mathrm{~b}$ & $16.5 \mathrm{c}$ \\
\hline Weeds & $\begin{array}{c}\text { 6 seeds of } \\
\text { Amaranthus } \\
\text { retrofleksus }\end{array}$ & $\begin{array}{c}2 \text { seeds of } \\
\text { Cuscuta spp }\end{array}$ & $\begin{array}{c}\text { 3.5 Plantago sp, } \\
\text { Matricaria } \\
\text { chamomilla } \\
20 \text { seeds of } \\
\text { Cuscuta spp }\end{array}$ \\
\hline Total & 100 & 100 & 100 \\
\hline
\end{tabular}

To obtain quality seeds, it is necessary to remove weeds from natural seeds immediately after harvest in order to avoid self-heating and seed contamination. The sieves of seed cleaning machines should be properly selected and arranged. The optimum air flow rate during the cleaning process should be maintained to prevent the quality seed from falling into the waste bins of the processing machine (Tarasenko et al., 2017). The determination and adjustment of parameters of the seed processing equipment is carried out depending on the purity and content of weeds in the seed sample (Đokić and Stanisavljević, 2012). The air flow and seed quantity during processing are the parameters that affect the total duration of the process, the obtained quantity of seeds, and the total seed losses (Đokić, 2010). An electromagnetic separator machine is used for the final cleaning of weed seeds. The quality of weed cleaning depends on the amount of seed passed through the magnetized cleaning rollers and the proper ratio between water and magnetic seed cleaning powder (Uhlarik et al., 2018). The data on the percentage of dodder seeds (Cuscuta spp) are relevant in practice as they indicate the efficiency of separation and the percentage of seeds lost in processing (Milošević et al., 1996). The average purity of alfalfa seeds obtained using the processing machines considered are shown in Table 3.

Table 3. The average purity of processed alfalfa seeds

\begin{tabular}{|c|c|c|c|}
\hline Lot & I & II & III \\
\hline Seed structure & $\%$ & $\%$ & $\%$ \\
\hline Pure seed & $96.2 \mathrm{a}$ & $98.6 \mathrm{a}$ & $99.0 \mathrm{a}$ \\
\hline Other species & 0 & 0 & $\begin{array}{c}0.2 \\
\text { red clover }\end{array}$ \\
\hline Inert matter & $3.8 \mathrm{a}$ & $1.4 \mathrm{ab}$ & $0.7 \mathrm{~b}$ \\
\hline Weeds & $\begin{array}{l}\text { in } 5 \text { g: } 3 \text { seeds } \\
\text { of Lolium } \\
\text { perene } \\
\text { and } 2 \text { seeds } \\
\text { of Setaria spp }\end{array}$ & $\begin{array}{l}\text { in } 5 \text { g: } 2 \text { seeds } \\
\text { of Matricaria } \\
\text { chamomilla, } \\
1 \text { seed of } \\
\text { Poa sp and } \\
2 \text { seeds } \\
\text { Polygonum sp }\end{array}$ & $\begin{array}{l}0.1 \text { in } 5 \text { g: } \\
1 \text { seed of } \\
\text { Amaranthus } \\
\text { retrofleksus } \\
\text { and } 2 \text { seeds } \\
\text { of Setaria spp }\end{array}$ \\
\hline Total & 100 & 100 & 100 \\
\hline
\end{tabular}

The purity of alfalfa seeds was high, ranging from $96.2 \%$ in the lot I seeds to $98.6 \%$ and $99.0 \%$ in lot II and III seeds, respectively. The lowest content of inert matter was recorded in the lot III seeds $(0.7 \%)$. The inert matter content of the lot II seeds was $1.4 \%$, consisting of empty seeds and harvest residues. The highest inert matter of $3.8 \%$ was found in the lot I seeds. A total of $0.2 \%$ of red clover seeds were found in the processed alfalfa lot III seeds. The $5 \mathrm{~g}$ working sample of the lot I seeds contained three perennial ryegrass (Lolium perene) seeds and two barnyard grass (Setaria spp) seeds. A total of two chamomile (Matricaria chamomilla) seeds, one mixed grass seed (Poa sp) and two knotgrass (Polygonum sp) seeds were found in the $5 \mathrm{~g}$ sample of the lot II seeds. There were $0.1 \%$ of weeds in the $5 \mathrm{~g}$ sample of the lot III seeds including one pigweed (Amaranthus retrofleksus) seed and two barnyard grass (Setaria spp) seeds. The average weed content of the seed samples analyzed was within the legal limits. The average purity of the three red clover seed lots considered is shown in Table 4 . The purity of the red clover seeds analysed was very high: $97.8 \%$ in the lot III seeds, $99.2 \%$ in the lot II seeds and $99.7 \%$ in the lot I seeds. A total of $0.6 \%$ of alfalfa seeds were found in the lot II seed sample, whereas two curly dock seeds (Rumex crispus) were found in the average $50 \mathrm{~g}$ sample of the lot II seeds. A total of $0.4 \%$ of alfalfa seeds were found in the lot III sample. The lot I seeds contained $0.1 \%$ of other species seeds (two tall fescue seeds). The lowest content of inert substances $(0.1 \%)$ was recorded in the lot I seeds. The lot II seeds had an inert substance content of $0.2 \%$. The highest content of inert matter (1.6\%) in the form of soil was found in the lot III seeds, as well as $0.2 \%$ of weeds (namely redroot pig weed (Amaranthus retroflexus) and chamomile (Matricaria chamomilla) seeds). Weeds accounted for $0.1 \%$ of the $5 \mathrm{~g}$ lot I seed sample with one plantain (Plantago sp) and two chamomile (Matricaria chamomilla) seeds found. A total of two curly dock (Rumex crispus) seeds were found in the average $50 \mathrm{~g}$ sample of the lot II seeds. No significant difference was found between the seed lots considered as confirmed by the Tukey's multiple range tests conducted ( $\leq \leq 0.05$; Tables 3 and 4$)$. The amount of natural seeds of all alfalfa and red clover lots considered, the amount of their processed seeds, the seed processing output and the seed losses on the processing machines used are shown in Table 5. The calculated values of processing output and machine losses are expressed in percent. In the alfalfa seed samples, the processing outputs varied from $59.1 \%$ in the lot I seeds to 75.58 $\%$ in the lot III seeds. The smallest losses in alfalfa seed processing were recorded in the lot III (14.43\%), whereas the greatest losses were recorded in the lot II (19.07\%). In the red clover seed samples, the processing output was found to be the lowest in the lot I (65.64 \%) and the highest in the lot II $(70.2$ $\%)$. The red clover seed losses on the processing machines used were the smallest in the seed lot I (11.3\%) and the greatest in the seed lot III (18.56 \%). On balance, the red clover seed losses were smaller than those of alfalfa as established by the Tukey's multiple range tests conducted (Table 5).

Table 4. The average purity of processed red clover seeds

\begin{tabular}{||c|c|c|c||}
\hline Lot & I & II & III \\
\hline Seed structure & $\%$ & $\%$ & $\%$ \\
\hline Pure seed & $99.7 \mathrm{a}$ & $99.2 \mathrm{a}$ & $97.8 \mathrm{a}$ \\
\hline Other species & $\begin{array}{c}0.1 \mathrm{c} \\
2 \text { tall fescue } \\
\text { seeds }\end{array}$ & $\begin{array}{c}0.6 \mathrm{a} \\
\text { alfalfa }\end{array}$ & $\begin{array}{c}0.4 \mathrm{~b} \\
\text { alfalfa }\end{array}$ \\
\hline Inert matter & $0.1 \mathrm{~b}$ & $0.2 \mathrm{~b}$ & $\begin{array}{c}1.6 \mathrm{a} \\
\text { soil }\end{array}$ \\
\hline & $\begin{array}{c}0.1 \text { in } 5 \mathrm{~g}: \\
2 \text { seeds of } \\
\text { Matricaria } \\
\text { chamomilla, } \\
1 \text { seed of } \\
\text { Plantago sp, }\end{array}$ & $\begin{array}{c}2 \text { seeds of } \\
\text { Rumex crispus }\end{array}$ & $\begin{array}{c}0.2 \\
\text { Amaranthus } \\
\text { retroflexus, } \\
\text { Matricaria } \\
\text { chamomilla }\end{array}$ \\
\hline Total & 100 & 100 & 100 \\
\hline \hline
\end{tabular}

Table 5. Alfalfa and red clover processed seeds, processing output and losses on the processing machines used

\begin{tabular}{|c|c|c|c|c|c|c||}
\hline \multirow{2}{*}{$\begin{array}{c}\text { Seed } \\
\text { structure }\end{array}$} & \multicolumn{7}{|c|}{ Species } \\
\cline { 2 - 7 } & \multicolumn{7}{|c|}{ Alfalfa } & \multicolumn{4}{|c|}{ Lot clover } \\
\cline { 2 - 7 } & $\mathrm{I}$ & II & III & I & II & III \\
\hline $\begin{array}{c}\text { Natural } \\
\text { seed (kg) }\end{array}$ & $1345.0 \mathrm{a}$ & $1000.0 \mathrm{c}$ & $1132.0 \mathrm{~b}$ & $1950.0 \mathrm{~b}$ & $1437.0 \mathrm{c}$ & $2350.0 \mathrm{a}$ \\
\hline $\begin{array}{c}\text { Processed } \\
\text { seed (kg) }\end{array}$ & $795.0 \mathrm{~b}$ & $696.0 \mathrm{c}$ & $833.0 \mathrm{a}$ & $1280.0 \mathrm{~b}$ & $1009.0 \mathrm{c}$ & $1531.0 \mathrm{a}$ \\
\hline $\begin{array}{c}\text { Processing } \\
\text { output (\%) }\end{array}$ & $59.1 \mathrm{c}$ & $69.6 \mathrm{~b}$ & $75.58 \mathrm{a}$ & $65.64 \mathrm{~b}$ & $70.2 \mathrm{a}$ & $65.15 \mathrm{~b}$ \\
\hline Losses (\%) & $15.56 \mathrm{~b}$ & $19.07 \mathrm{a}$ & $14.43 \mathrm{~b}$ & $11.3 \mathrm{~b}$ & $12.23 \mathrm{~b}$ & $18.56 \mathrm{a}$ \\
\hline \hline
\end{tabular}




\section{CONCLUSION}

The purpose of processing alfalfa and red clover seeds is to obtain as much quality seed as possible. The processing output of the alfalfa seed lots considered ranged from $59.1 \%$ in the lot I to $75.58 \%$ in the lot III. The alfalfa seed losses on the processing machines used ranged from $14.43 \%$ in the lot III to $19.07 \%$ in the lot II. The processing output of the red clover seed lots considered ranged from $65.15 \%$ in the lot III to $70.2 \%$ in the lot II. The red clover seed losses were the smallest in the lot I (11.3 \%) and the greatest in the lot III (18.56 \%). In order to ensure good seed cleaning, appropriate cleaning techniques should be applied with as little seed loss as possible. Natural seeds of poor purity and quality lead to seed losses during the cleaning process. Therefore, the machines for seed processing should be properly selected and adjusted, depending on the amount and type of weeds and impurities found in natural seeds. The results obtained indicate that the processing of natural alfalfa and red clover seeds and the processed seed output depend on the initial purity of natural alfalfa and red clover seeds, i.e. the presence and type of quarantine weeds.

ACKNOWLEDGEMENT: This paper is a result of the research project 31057, which was financed by the Ministry of Education, Science and Technological Development of the Republic of Serbia.

\section{REFERENCES}

Babić, M., Babić, Ljiljana (2012). Sušenje i skladištenje. II izdanje. Univerzitet u Novom Sadu, Poljoprivredni fakultet, Novi Sad, Srbija.

Баскаков, И., Карпенко, Р., Оробинский, В. (2018). Зерноочистителъные машины и элеваторное оборудование производства ООО "Воронежсельмаш", ФГБОУ ВО "Воронежский государственный аграрный университет имени императора Петра I", г. Воронеж, Россия.

Black, M., Bewley, J., Halmer, P. (2006). The Encyclopedia of Seed Science, technology and uses. Wallingford, UK.

Copeland, L., McDonald, M. (2004). Seed Drying. Seed Science and Technology, Norwell, Massachusetts.

Đokić D. (2010). Primena različitih tehničko-tehnoloških sistema u doradi semena lucerke. Doktorska disertacija, Univerzitet u Beogradu. Poljoprivredni fakultet, Beograd, Srbija.

Đokić, D., Stanisavljević, R. (2012). Possibility of Improving Seed Processing of Red Clover (Trifolium pratense L.) and Alfalfa (Medicago sativa L.). Book of the proceedings International Conference on BioScience: Biotechnology and Biodiversity - Step in the Future - The Forth Joint UNS - PSU Conference Novi Sad, Serbia, June 18-20, Institut za ratarstvo i povrtarstvo, Semenarska asocijacija Srbije, 135-148.

Đokić, D., Stanisavljević, R., Terzić, D., Marković, J., Radivojević, G., Anđelković, B., Barać, S. (2012). Primena različitih tehnoloških procesa u doradi semena crvene deteline. Poljoprivredna tehnika, 37(3), 1-10.

Đokić, D., Stanisavljević, R., Terzić, D., Milenković, J., Lugić, Z., Barać, S., Vuković, A. (2016). Uticaj korovskih vrsta na efikasnost dorade semena crvene deteline (Trifolium pratense L.). Naučno-stručni skup: Aktuelni problemi mehanizacije poljoprivrede. Zbornik radova, Beograd: str. 29-37.

Đokić, D., Stanisavljević, R., Terzić, D., Milenković, J., Lugić, Z., Koprivica, R., Barać, S. (2017). The impact of the natural seed purity on the final quantity of seeds of red clover (Trifolium pratense L.) after processing. Book of proceedings, VIII International Scientific Agriculture Symposium, October 05.-08.2017, Jahorina, Bosnia and Herzegovina, 513-518.
Đokić, D., Stanisavljević, R., Terzić, D., Milenković, J., Lugić, Z., Radović, J., Knežević, J. (2018). Određivanje relevantnih parametara pri doradi semena crvene deteline (Trifolium pratense L.). Selekcija i semenarstvo, 24(1), 57-64.

Đukić, D., Moisuc, A., Janjić, V., Kišgeci, J. (2004). Krmne, korovske, otrovne i lekovite biljke. Poljoprivredni fakultet, Novi Sad.

Glasnik Republike Srbije br. 45. (Gazette of the Republic of Serbia No. 45, (2005)

Karagić. Đ., Katić, S., Vasiljević, S., Milić, D. (2007). Semenarstvo lucerke u Vojvodini. XI simpozijum o krmnom bilju Republike Srbije sa međunarodnim učešćem, Novi Sad, Srbija, 87-98.

Knežević, Jasmina, Stanisavljević, R. (2018). Posebno ratarstvo: industrijsko i krmno bilje. Univerzitet u Prištini, poljoprivredni fakultet Lešak, Srbija.

Koprivica R. (2018) Uticaj sorte i vremena berbe na osnovne fizičke i mehaničke osobine ploda i zrna uljane repice. Doktorska disertacija. Univerzitet u Kragujevcu, Agronomski fakultet u Čačku.

Козлов, В. (2013). Пневномагнитная сепарация. Совершенствование процесса сепарации мелкосеменных кулътур. LAP LAMBERT Academic Publishing, Saarbrücken, Deutschland.

Lugić, Z., Radović, J., Terzić, D., Tomić, Z., Spasić, R. (2000). Semenarstvo višegodišnjih leguminoza u centru za krmno bilje Kruševac. XI savetovanje, Semenarstvo krmnog bilja na pragu trećeg milenijuma, Sombor, 47-55.

Marković, J., Ignjatović, S., Radović, J., Lugić, Z. (2007). Uticaj faze razvića na sadržaj makro i mikroelemenata u lucerki i crvenoj detelini. Zbornik radova Instituta za ratarstvo i povrtarstvo, Novi Sad, (44),401-406.

Milošević, M., Marjanović, J., Vujaković, M., Polovina, R., Pataki, I., (1996). Vilina kosica u lucerki i mogućnost njenog uklanjanja iz semena. Zbornik radova. VIII jugoslovenski simpozijum o krmnom bilju sa međunarodnim učešćem, (26)175-179, Novi Sad.

Ocokoljić Stojanka (1974). Leptiraste biljke u ishrani stoke (lucerka, crvena detelina, žuti zvezdan), Nolit, Beograd.

Оробинский, В., Корнев, А., Тертычная, Т., Шварц, А. (2017). Совершенствование технологии получения качественных семян подсолнечника. Вестник Воронежского государственного аграрного университета, ФГБОУ ВО, Воронежский ГАУ, Воронеж, 4(44), 103-106.

Službeni list SFRJ br.47. Pravilnik o kvalitetu semena poljoprivrednog bilja (1987). (Official gazette SFRJ, No. 47/87. Rule on the quality of seeds of agricultural plants. 1987)

Тарасенко, А., Оробинский, В., Гиевский, А., Тарабрин, Д., Анненков, М. (2017). Обоснование принципиалъной схемы воздушно-решетного сепаратора семян. Вестник Воронежского государственного аграрного университета, ФГБОУ ВО, Воронежский ГАУ, Воронеж, 4(44), 95-102.

Uhlarik, A., Popov, S., Karagić, Đ., Ponjičan, O., Turan, J. (2018). Alfalfa seed cleaning using a magnetic separator. Journal on Processing and Energy in Agriculture, 22(4), 192195.

Vasiljević, S., Katić, S., Mihailović, V. (2011). Oplemenjivanje crvene deteline (Trifolium pratense L.) na poboljšan kvalitet krme. Zbornik referata, 45 savetovanje agronoma Srbije, Zlatibor, 30. 01.-05. 02. 127-137.

Vučković, S. (1999). Krmno bilje. Beograd: Institut za istraživanje u poljoprivredi "Srbija", Nova Pazova "Bonart".

Received: 24.02.2020.

Accepted: 09.04.2020. 